\title{
Feeding variations and shape changes of a temperate reef clingfish during its early ontogeny
}

\author{
Valentina Bernal-Durán, Mauricio F. Landaeta \\ Laboratorio de Ictioplancton (LABITI), Facultad de Ciencias del Mar y de Recursos Naturales, Universidad de Valparaíso, \\ Avenida Borgoño 16344, Reñaca, Viña del Mar, Chile. \\ (VB-D) E-mail: valebernald@ gmail.com. ORCID-iD: http://orcid.org/0000-0002-0567-910X \\ (MFL) (Corresponding author) E-mail: mauricio.landaeta@uv.cl. ORCID-iD: http://orcid.org/0000-0002-5199-5103
}

\begin{abstract}
Summary: The majority of rocky reef fishes have complex life cycles, involving transition from a pelagic to a benthic environment. This means that as they grow, their morphology, behaviour and feeding habits must change. Therefore, shape changes occurring during early development of these fishes will be related to diet changes. The clingfish Sicyases sanguineus was selected for this study, because it displays a noticeable variation in shape from pelagic larvae to juvenile stage, and it is expected that diet composition will change as well. The pattern of shape changes was studied using geometric morphometrics. A set of 9 landmarks were digitized in 159 larval and juvenile fish and the same specimens were used for gut content analysis. Allometric growth was most prominent early in the ontogeny, from 4 to $12 \mathrm{~mm}$. Morphology changed from a thin and hydrodynamic shape to a more robust and deeper body prior to settlement. The diet of the clingfish during larval stages showed preferences for a variety of copepod stages. As individual grows the ingested prey volume increases, but not the number and width of prey. A partial least square analysis showed low covariance between shape changes and diet composition changes in prey number and volume, suggesting that the two processes were temporally decoupled. The biggest shape changes, a lengthening of the visceral cavity and a flattening of the head, occurred up to $12 \mathrm{~mm}$ standard length, while the largest feeding differentiation, shifting from copepods to microalgae, occurred after $16 \mathrm{~mm}$. Results suggest that shape changes precede trophic changes in this clingfish species during the transition from a pelagic to a benthic habitat.
\end{abstract}

Keywords: ecomorphology; feeding ecology; ontogeny; geometric morphometrics; Gobiesocidae.

Variaciones en la alimentación y cambios de forma de un pejesapo de arrecife temperado durante la ontogenia temprana

Resumen: La mayoría de los peces de arrecifes rocosos tienen ciclos de vida complejos, que involucran la transición de un ambiente pelágico a uno bentónico. Esto significa que a medida que un pez crece, su morfología, conducta y alimentación cambian. Por lo tanto, los cambios de forma que ocurren durante la ontogenia temprana estarán relacionados con los cambios dietarios en peces de arrecifes rocosos. Se seleccionó el pejesapo Sicyases sanguineus para este estudio porque presenta una notable variación en forma desde la larva pelágica al estado juvenil, y es esperable que la composición dietaria también cambie. El patrón de cambios de forma fue estudiado usando morfometría geométrica. Se digitalizó un total de 9 landmarks en 159 larvas y juveniles, y los mismos individuos se usaron para análisis de contenido estomacal. El crecimiento alométrico fue mayor al comienzo del desarrollo ontogenético, entre 4 y $12 \mathrm{~mm}$. La forma cambió de delgada e hidrodinámica, a más robusta y profunda antes del asentamiento. La dieta de las larvas de pejesapo mostró preferencia por diferentes estados de desarrollo de copépodos. A medida que los individuos crecieron, se incrementó el volumen de las presas ingeridas, pero no el número o ancho de ellas. Un análisis de Cuadrados Mínimos Parciales mostró baja covarianza entre los cambios morfológicos y dietarios en número y volumen de presas, sugiriendo que ambos procesos están temporalmente desacoplados. Los mayores cambios morfológicos ocurrieron antes de los $12 \mathrm{~mm}$, un alargamiento de la cavidad visceral y un aplanamiento de la cabeza, mientras que la mayor diferenciación dietaria ocurrió después de los $16 \mathrm{~mm}$, cambiando de copépodos a macroalgas. Esto sugiere que los cambios morfológicos preceden a los cambios en dieta en esta especie de pejesapo durante la transición de un hábitat pelágico a uno bentónico.

Palabras clave: ecomorfología; ecología trófica; ontogenia; morfometría geométrica; Gobiesocidae.

Citation/Como citar este artículo: Bernal-Durán V., Landaeta M.F. 2017. Feeding variations and shape changes of a temperate reef clingfish during its early ontogeny. Sci. Mar. 81(2): 205-215. doi: http://dx.doi.org/10.3989/scimar.04555.09A

Editor: J.J. Govoni.

Received: September 23, 2016. Accepted: February 15, 2017. Published: May 2, 2017.

Copyright: (9 2017 CSIC. This is an open-access article distributed under the terms of the Creative Commons Attribution (CC-by) Spain 3.0 License. 


\section{INTRODUCTION}

Most coral and rocky reef fishes have stagestructured life histories with two main distinct stages including a pelagic larval stage and a demersal stage (generally juveniles and adults; Gonçalves et al. 2002, Lecchini 2005, Hernández-Miranda et al. 2009). The settlement phase, which is the transition from the pelagic environment to the benthic reef environment is a key period, because during this phase fish often undergo a change in form and physiology to a mode suited for the new environment (McCormick and Makey 1997), which also produces changes in behaviour and feeding habits (Russo et al. 2007, Frédérich et al. 2008, 2012, Usmar 2012).

Fish morphology plays a major role in determining diet, because variations in morphology are assumed to underlie variation in feeding ability, and variation in the latter is expected to affect diet (Wainwright and Richard 1995). The assumed link between morphology and diet in fishes is provided by feeding performance (Norton 1991, Wainwright 1991, Motta and Kotrschal 1992, Costa and Cataudella 2007), because morphology influences the fish feeding abilities by limiting the prey that the individual it is able to capture and handle. Body size is important in diet shifts of fishes; as individuals grow, their feeding habits also change. Nonetheless, the shape of the feeding apparatus also changes throughout early development, and morphology plays a central role in determining the minimal, maximal and optimal prey sizes (Wainwright and Richard 1995).

Allometry is the pattern of covariation among several morphological traits or between measures of size and shape (Gould 1966). It can be used to summarize the developmental history of growing parts of an animal (Weston 2003) and contributes to the integration of morphological traits (Klingenberg 2016). Allometry, the variation in shape that is associated with variations in size, is widely characterized by multivariate regression of shape on size (log-transformed centroid size; Loy et al. 1998, Mitteroecker et al. 2004). Allometric variation can amount to a sizeable proportion of total shape variation, and can contribute substantially to overall integration of shape (Sidlaukas et al. 2011, Klingenberg 2016).

Geometric morphometric techniques are one way to visualize the patterns of allometric growth occurring during the transition from the larval to the settled phase, because this approach allows a mathematical quantification of the changes in size and shape (Bookstein 1991). Geometric morphometrics deals directly with coordinates of anatomical landmarks, either in two or three dimensions, rather than with traditional distance or angle measurements. Landmark points have been defined by Bookstein (1991) as loci that have names as well as Cartesian coordinates, and are intended to imply true homology (biological correspondence) from form to form. Landmark-based geometric morphometrics has been used to study morphological changes among fishes from the same family (Cavalcanti et al. 1999, Lopes et al. 2006, Ponton et al. 2013), changes in fish scales (Ibáñez et al. 2007), allometric patterns and related shape changes in skeletal units (Frédérich et al. 2008), and the evolution of certain fish families (Kerschbaumer and Strumbauer 2009). However, few studies have dealt with shape changes during early life history. For example, Loy et al. (1998) used geometric morphometrics to characterize shape changes during early juvenile life of Diplodus vulgaris and found that the growth trajectory resembles a theoretical saturating growth curve, where shape change is fast for small sizes and slows down with an increase in size. The same pattern of growth trajectories was described by Russo et al. (2007, 2009), studying the shape changes throughout ontogeny of Sparus aurata and Epinephelus marginatus using geometric morphometrics. They defined a two-stage growth curve, where the first stage is characterized by a dramatic morphological change for a small size interval, and the second by a change in size not accompanied by a change in shape. In both cases the steep portion of the growth trajectory corresponds to the size range in which the habitat transition occurs.

The clingfish Sicyases sanguineus Müller and Troschel, 1843 was selected as a species for studying ontogenetic shape changes, because clingfish display a notable variation in shape from pelagic larvae to juvenile fish (Pérez 1981, Gonçalves et al. 2002, Tojeira et al. 2012). Larval $S$. sanguineus hatch at relatively large size (>3-5 mm, Pérez 1981) during the thirdquarter moon and full moon and grow at relatively slow rates $\left(0.14 \mathrm{~mm} \mathrm{day}^{-1}\right)$ during the initial 25 days (Contreras et al. 2013). In this species, the sucker disc starts to form around $10 \mathrm{~mm}$ body length, and the process ends around $17 \mathrm{~mm}$ (Pérez 1981). Adults are generalist feeders, feeding on macroalgae and a wide range of molluscs, crustaceans and echinoderms (Paine and Palmer 1978, Muñoz and Ojeda 1997). However, there is no information about the feeding habits during larval development. Therefore, the goal of this study was to determine variations in feeding habits, to describe shape changes (utilizing geometric morphometrics) and to study the relationship between these two processes, which occur during the transition from the pelagic to the settled stages of $S$. sanguineus. Our hypothesis is that morphometric and shape changes occurring throughout clingfish early development are related to significant variations in diet composition and to feeding success.

\section{MATERIALS AND METHODS}

\section{Field work}

Fish larvae were collected from nearshore waters off Montemar $\left(32^{\circ} 57^{\prime} \mathrm{S}, 71^{\circ} 33^{\prime} \mathrm{W}\right)$ and El Quisco $\left(33^{\circ} 24^{\prime} \mathrm{S}, 71^{\circ} 43^{\prime} \mathrm{W}\right)$, central Chile. During the austral spring of 2011-2013, zooplankton samples were collected using a Bongo net $(60 \mathrm{~cm}$ mouth diameter, 300 $\mu \mathrm{m}$ mesh size), equipped with a TSK flow meter (The Tsurumi-Seiki Co., Ldt. Tsurumi.Ku, Yokohama, Japan) to quantify the filtered seawater. Tows were done from surface to near-bottom depths ( $20 \mathrm{~m})$ during the 
dawn and night hours (1900 to $2300 \mathrm{~h}$ ) at 1 nautical mile from the coastline. Five to 8 trawls at $1-2$ knots were conducted during each oceanographic sampling at the same location. The seawater filtered by the net ranged from 13.3 to $437.4 \mathrm{~m}^{3}$ (mean \pm standard deviation; $\left.141.2 \pm 102.5 \mathrm{~m}^{3}\right)$. All plankton samples $(\mathrm{n}=314)$ were initially fixed in $5 \%$ formalin buffered with sodium borate, and after $12 \mathrm{~h}$ they were preserved in $96 \%$ ethanol.

Additionally, juvenile fish were collected with hand nets in the intertidal zone off Las Cruces $\left(33^{\circ} 29^{\prime} \mathrm{S}\right.$; $71^{\circ} 37^{\prime} \mathrm{W}$ ) during April 2015. Individuals were immersed in sea water with benzocaine in excess for a bioethical death, and later preserved in $96 \%$ ethanol.

\section{Laboratory work}

All fish larvae were sorted in the laboratory from the plankton samples. Identification of larval S. sanguineus followed Pérez (1981). Individuals were measured under an Olympus SZ-61 stereomicroscope with a Moticam 2500 video camera (5.0MPixel) connected to a PC with Moticam Image Plus 2.0 software. Later, larvae were divided into four size groups: $<8 \mathrm{~mm}, 8-12$ $\mathrm{mm}, 12-16 \mathrm{~mm}$ and $>16 \mathrm{~mm}$ standard length (SL). Larvae measurements were not corrected for shrinkage. Juveniles were measured with a caliper after fixation in ethanol.

\section{Geometric morphometrics}

A set of 9 landmarks were digitized in lateral views of the 159 larval and juvenile fish (Fig. 1) following suggestions of Farré et al. (2016), using TpsDig (version 2.17). Shape information was extracted from the landmark coordinates with a generalized Procrustes analysis (GPA; Dryden and Mardia 1998), using MorphoJ (version 1.05f, Klingenberg 2011). GPA removes non-shape variation by scaling, translating and rotating all specimens to one consensus configuration (Rohlf and Slice 1990). Then the shape coordinates can be used to visualize and perform any type of statistical analysis (Kerschbaumer and Sturmbauer 2009). Residuals from this superimposition were analysed with the thin-plate spline interpolating function (Bookstein 1991). The digitizing procedure was repeated for 25 randomly selected cases, each specimen was slightly rotated and photographed twice and Procrustes analysis of variance (Procrustes ANOVA) was carried out to assess the relative amounts of variation among individuals and of measurement error using MorphoJ software (Klingenberg 2011).

To quantify the allometry, a regression of shape represented by Procrustes coordinates (landmark coordinates after Procrustes superimposition representing the shape of an object; Mitteroecker and Gunz 2009) on size, represented by centroid size (CS) was performed in MorphoJ software.

Principal component analysis was performed with the shape coordinates to identify the main axes of shape change and the specific changes in the larval body (reflected as movements of landmarks) that ex-
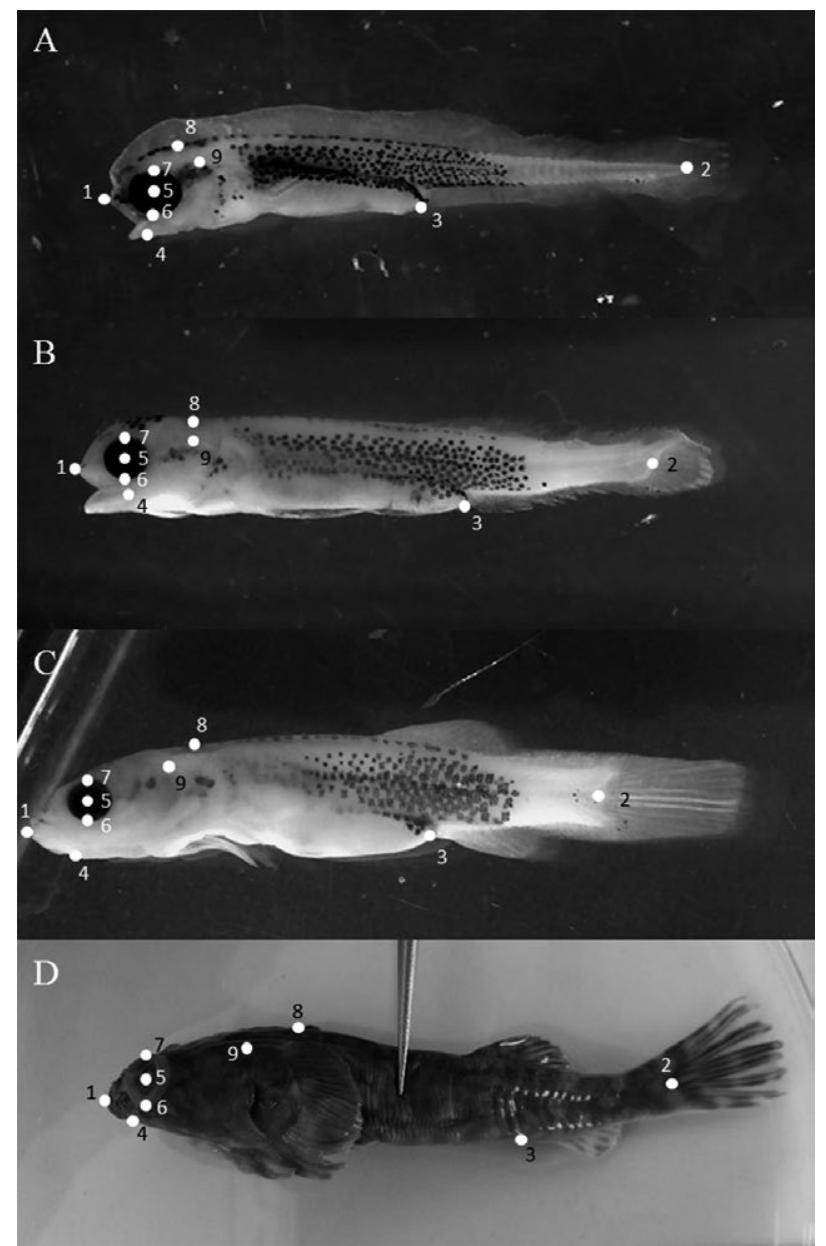

Fig. 1. - Landmark position in preflexion (A), flexion (B) and postflexion larvae (C), and juveniles (D) of S. sanguineus, where 1, tip of the premaxilla; 2, posterior body extremity; 3, anus; 4, posterior extremity of premaxilla; 5 centre of the eye; 6 and 7, lower and upper margin of the eye; 8, posterior extremity of occiput; and 9, insertion of operculum.

plain the variability of the data. For the visualization of the shape changes, a warping transformation grid was used, following Klingenberg (2013), in addition to classical transformation grids (Russo et al. 2007, 2009).

\section{Gut content analysis}

The same 159 larval and juvenile fish were utilized for gut content analysis. The gut of each larva was dissected from the body and opened length-wise with fine needles. Prey items were counted and identified to the lowest possible taxon under a Motic BA310 microscope at $10 \times-40 \times$ magnification. The maximum SL and width of each prey item (maximum prey width, MPW) were measured with the microscope and a Motic Moticam 2500 camera (resolution 5.0 MPixel) using the Motic Image Plus 2.0 software. The volume of each prey item (i.e. copepods, nauplii, etc, ) was estimated using the three-dimensional shape that most closely resembled the item, following Cass-Calay (2003) and Sun and Liu (2003). The prosome length of copepodite prey was measured because the urosome was often missing. 
The feeding incidence (FI) was calculated as a percentage of larvae with any gut content, in relation to the total number of larvae examined (Sassa and Kawaguchi 2004). Comparisons of FI among size ranges were carried out with contingence tables.

The diet was described using the percent frequency of occurrence $(\% \mathrm{~F})$ of a diet item in larvae with food in their guts, the percent of the total number $(\% \mathrm{~N})$ of diet items that were examined and the percent of volume $(\% \mathrm{~V})$ of each item out of the total volume of prey items. An index of relative importance (IRI) was calculated as follows: $\mathrm{IRI}=(\% \mathrm{~N}+\% \mathrm{~V}) \times \% \mathrm{~F}$. To readily allow comparisons among prey items, the IRI was the standardized to \%IRI for each prey item (Cortés 1997).

To establish the variability in the feeding success of $S$. sanguineus, three measures of feeding success were calculated: the number of prey items per gut (PIPG, number), total prey volume per gut $\left(\mathrm{TPVG}, \mathrm{mm}^{3}\right)$ and MPW ( $\mu \mathrm{m})$ (Reiss et al. 2002, Landaeta et al. 2011, 2015). Because these indicators of feeding success may vary with larval size, one-way ANCOVA was utilized for inter-size comparisons, using SL as covariate.

Pearre's trophic niche breadth (Pearre 1986) was adopted to analyse the relationship between prey size and predator size. This model uses the standard deviation (SD) of the $\log _{10}$-transformed prey size as a measure of trophic niche breadth. In this analysis, clingfish larvae and juveniles were classified according to body length at $0.5-\mathrm{mm}$ intervals. Only fish with more than two prey items in the gut were used for further analysis. The mean and SD of the $\log _{10}$-transformed prey width was calculated for each available size class of clingfish. The relationship between SL and the corresponding mean and SD of the $\log _{10}$-transformed prey size was examined using linear regression analysis to determine any shifts in niche breadth with SL.

To establish the differences in the composition of prey among size ranges, a multivariate approach was utilized. The prey composition (number of prey) of each larva was utilized for the generation of BrayCurtis similarity matrices. A permutational multivariate analysis of variance (PERMANOVA, Anderson 2001), which is analogous to a univariate analysis of variance, was utilized to determine the differences in prey composition among size ranges. Finally, similarity percentage analyses (SIMPER) were carried out to explain aspects of the similarity between diet and larval size ranges.

\section{Comparison of shape changes and feeding habits}

To determine the covariation pattern between shape and diet along the early development of $S$. sanguineus, a partial least squares (PLS) analysis was performed. PLS is a method for exploring patterns of covariation between two blocks of variables and can be used to analyse the relationship between form and function (Zelditch et al. 2012). Additionally, the number of variables can greatly exceed the number of cases, making PLS useful for discriminating between groups when there are far more shape variables than specimens. This
Table 1. - Summary of Procrustes ANOVA for estimating the measurement error in the digitalization of landmarks on larval and juvenile Sicyases sanguineus.

\begin{tabular}{lccccc}
\hline Effect & SS & Df & MS & F & P \\
\hline Individual & 0.523 & 384 & 0.0013 & 52.19 & $<0.0001$ \\
Error & 0.010 & 400 & $2.61 \times 10^{-5}$ & & \\
\hline
\end{tabular}

kind of analysis has been used before to study the covariation between shape and diet changes (Klingenberg and Ekau 1996, Russo et al. 2008). PLS analysis were performed, using one block as the shape coordinates (after Procrustes analysis) and other block of diet composition (prey number or prey volume). These analyses were done to determine coupling or independence of shape and diet changes in early stages of clingfish.

\section{RESULTS}

\section{Geometric morphometrics}

Procrustes ANOVA indicates that measurement error was $1.91 \%$ (Table 1). The relationship between CS and SL was well expressed by a linear model $\left(\mathrm{R}^{2}=0.979\right.$, $\mathrm{P}<0.01)$, and CS is therefore a good proxy of the indi-
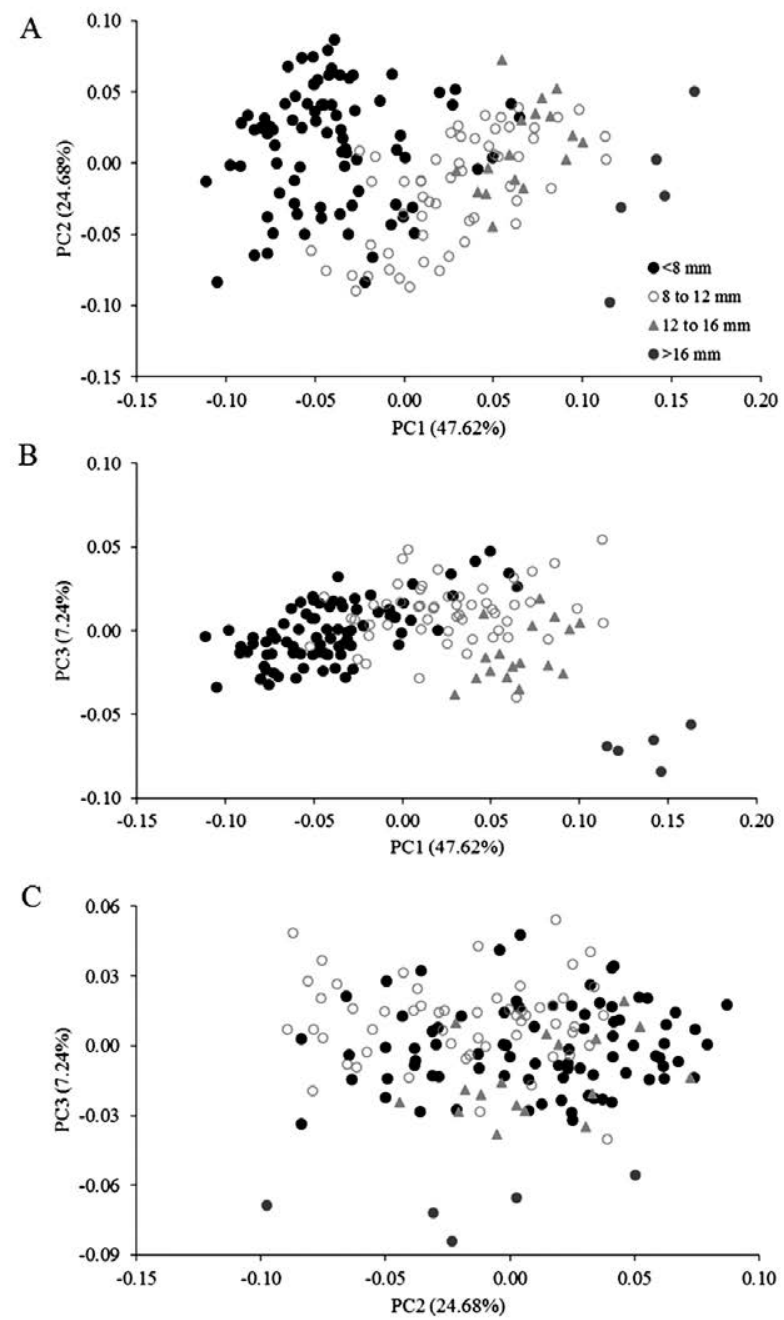

Fig. 2. - Principal component analysis: the principal morphometric changes axes during ontogenetic development of $S$. sanguineus. 
Table 2. - Principal Component Analysis. PC, principal component. The highlighted cells correspond to the extreme values (in magnitude) of factor loadings for each PC, and indicate landmark coordinates that make a greater contribution to the larval shape variation.

\begin{tabular}{lcccc}
\hline \multicolumn{1}{c}{ Landmarks } & & & PCs & \\
& X-Y & PC1 & PC2 & PC3 \\
\hline \multirow{2}{*}{ Tip of the premaxilla } & x1 & -0.166 & 0.066 & $\mathbf{- 0 . 4 2 7}$ \\
& y1 & -0.170 & 0.382 & 0.219 \\
Posterior body extremity & x2 & $\mathbf{- 0 . 4 7 4}$ & 0.089 & -0.144 \\
& y2 & 0.033 & $\mathbf{0 . 4 5 4}$ & 0.106 \\
Anus & x3 & $\mathbf{0 . 6 2 6}$ & -0.137 & 0.017 \\
& y3 & -0.048 & $\mathbf{- 0 . 4 2 2}$ & -0.155 \\
Posterior extremity of premaxilla & x4 & -0.275 & -0.193 & 0.034 \\
& y4 & 0.058 & 0.069 & -0.091 \\
Centre of the eye & x5 & -0.083 & -0.046 & 0.053 \\
& y5 & 0.021 & 0.079 & -0.084 \\
Inferior margin of the eye & x6 & -0.071 & 0.021 & 0.082 \\
& y6 & 0.015 & 0.075 & -0.033 \\
Superior margin of the eye & x7 & -0.105 & -0.106 & 0.019 \\
Posterior extremity of & y7 & 0.015 & 0.115 & -0.112 \\
supraoccipital bone & x8 & $\mathbf{0 . 4 5 6}$ & 0.252 & $\mathbf{- 0 . 3 6 0}$ \\
Insertion of operculum & y8 & 0.059 & -0.311 & 0.019 \\
Eigenvalues & x9 & 0.093 & 0.054 & $\mathbf{0 . 7 2 5}$ \\
\% Variance & y9 & 0.018 & $-\mathbf{0 . 4 4 2}$ & 0.132 \\
\hline
\end{tabular}

vidual length. The first three principal components of shape explained most of the variance $(79.54 \%)$ of the shape changes during early ontogeny of $S$. sanguineus (Fig. 2 and Table 2). PC1 (47.62\% of the total Procrustes form variance) expresses a lengthening of the visceral cavity (given by a noticeable displacement in the horizontal axis of the LM3, corresponding to the anus) during the formation of the sucker, as well as a shortening of the tail and a lengthening of the head. The factor loadings for the landmarks representing these shape changes were the greatest in magnitude in this PC (anus, 0.626; posterior body extremity, -0.474 ; posterior extremity of supraoccipital bone, 0.456; Fig. 3A). PC2 (24.68\%) shows a dorsal displacement of the tail as well as changes in the body height, with an increase in the height at the level of the anus and a flat-

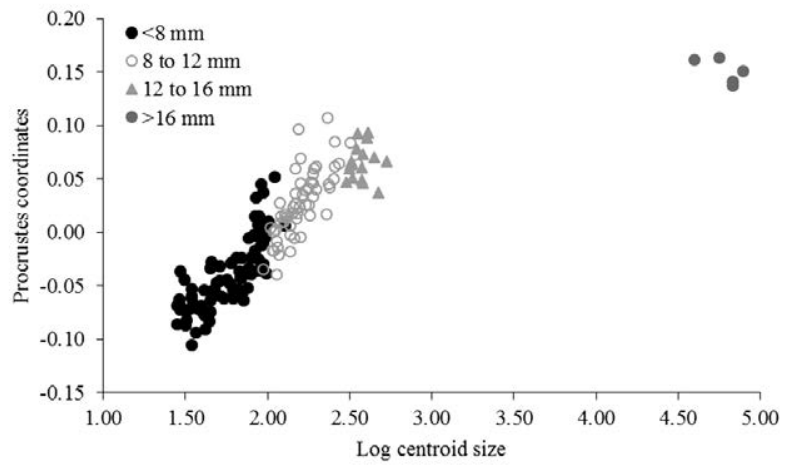

Fig. 4. - Regression between Procrustes coordinates and logarithm of centroid size: morphometric change occurrence and allometry during the early ontogenetic development of $S$. sanguineus.

tening of the head (factor loadings of posterior body extremity, 0.454 ; anus, -0.422 ; insertion of operculum, -0.442 ; Fig. 3B). The PC3 accumulated low variance (7.24\%), showing a lengthening of the head caused by an increase in the distance between the premaxilla tip and the opercle insertion as well as a lengthening of the premaxilla (factor loadings of insertion of operculum, 0.725 ; tip of the premaxilla, -0.427 ; Fig. 3 C).

The regression between Procrustes coordinates and CS was significant $(\mathrm{P}<0.001)$ and allometry accounted for $31.69 \%$ of the shape change during the transition of a pelagic larval to a benthic juvenile (Fig. 4). The allometric growth occurred early in the ontogeny of $S$. sanguineus mainly between 4 and $12 \mathrm{~mm} \mathrm{SL}$. After that size, the shape change was comparatively low (Fig. 4).

\section{Feeding incidence and diet composition}

The FI was high throughout the SL analysed, ranging between $80 \%$ and $94.12 \%$ (Table 3 ). No significant differences in the FI were detected among size groups $\left(\chi^{2}=0.974, \mathrm{P}=0.807\right)$, suggesting that the foraging was independent of the larval fish size.
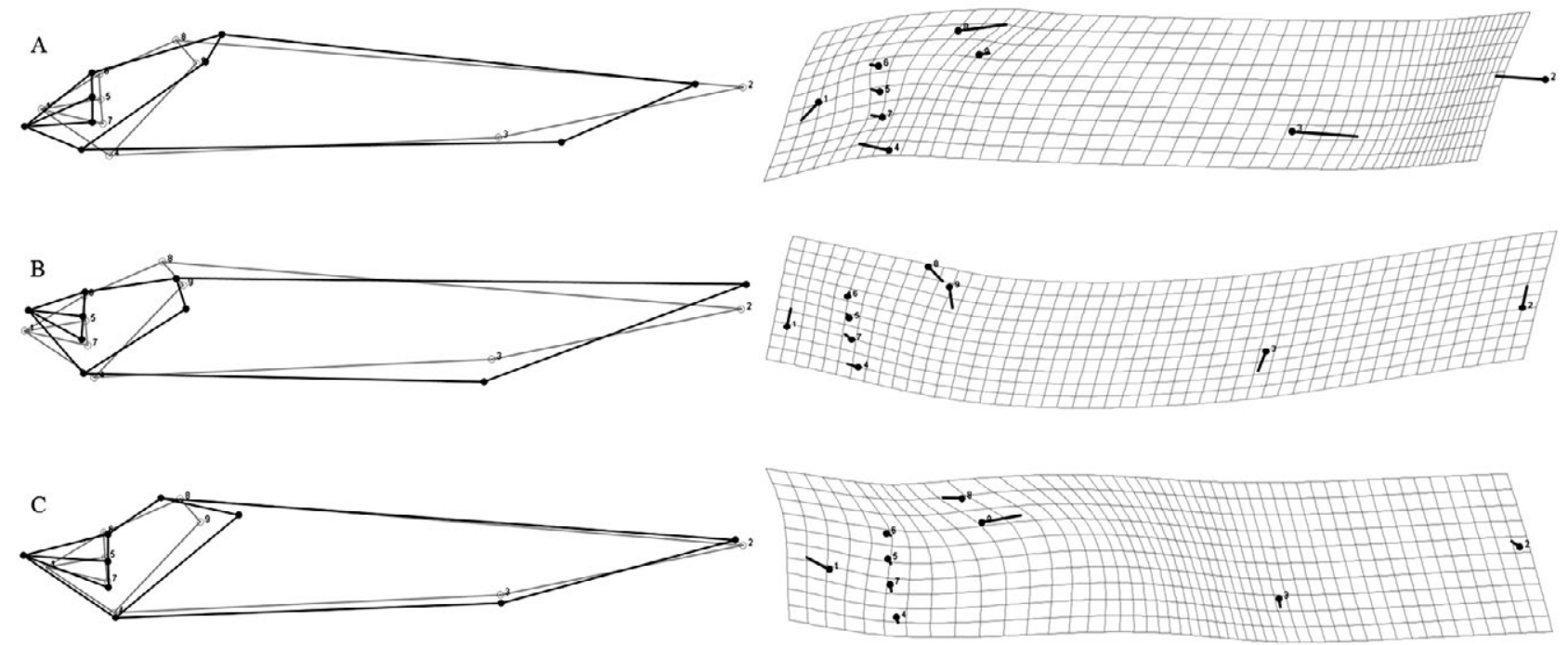

Fig. 3. - Morphometric change visualization in the three first principal components: (A) wireframe and transformation grid of PC1; (B) wireframe and transformation grid of $\mathrm{PC} 2 ; \mathrm{C}$, wireframe and transformation grid of $\mathrm{PC} 3$. The wireframes and the grids refer to shape changes from negative to positive values along PC axis. 
Table 3. - Size variation of the feeding incidence (FI) of clingfish Sicyases sanguineus from central Chile. WC, with content; WoC, without content.

\begin{tabular}{lccc}
\hline Size range $(\mathrm{mm})$ & WC & WoC & FI $(\%)$ \\
\hline$<8$ & 75 & 7 & 91.46 \\
$8-12$ & 50 & 5 & 90.91 \\
$12-16$ & 16 & 1 & 94.12 \\
$>16$ & 4 & 1 & 80.00 \\
\hline
\end{tabular}

A total of 43 prey items were identified in the gut contents of larval and juvenile $S$. sanguineus, showing a specialization for each size group (Table 4). In the smaller larvae $(<8 \mathrm{~mm} \mathrm{SL})$, the diet was dominated by copepod nauplii (42.45\% \% IRI), an item with high values of $\% \mathrm{~N}(29.36 \%), \% \mathrm{~V}(15.31 \%)$ and $\% \mathrm{~F}$ $(62.20 \%)$. Other important prey items in this size range were cirriped nauplii (16.79\% \%IRI) and dinoflagel- late cysts (13.85\%). Larvae between 8 and $12 \mathrm{~mm} \mathrm{SL}$ also preyed mainly on copepod nauplii $(31.85 \%)$ and cirriped nauplii $(23.95 \%)$; however, in this size range, individuals reduced the ingestion of phytoplankton down to $8.34 \% \%$ IRI, with a $\% \mathrm{~V}$ of $2.04 \%$ (Table 4 ). In this size group, fish eggs of at least two pelagic species, anchoveta Engraulis ringens and mote sculpin Normanichthys crockery, appeared as volumetrically important items $(\sim 43 \%)$. Specimens between 12 and 16 $\mathrm{mm}$ SL showed a preference for adult calanoid copepods, such as Paracalanus indicus (39.44\% \% IRI), gasteropod larvae (14.91\%) and copepod nauplii $(9.42 \%)$. The frequency of phytoplankton in the gut contents was low $(11.76 \% \% \mathrm{~F})$ and almost irrelevant as a prey item $(0.48 \%$ \%IRI; Table 4$)$. On the other hand, juvenile, completely transformed fishes (>16 mm SL)

Table 4. - Diet composition of larval and juvenile clingfish Sicyases sanguineus by size groups.

\begin{tabular}{|c|c|c|c|c|c|c|c|c|c|c|c|c|c|c|c|c|}
\hline \multirow{2}{*}{ Prey ítems } & \multicolumn{4}{|c|}{ Group $1(<8 \mathrm{~mm})$} & \multicolumn{4}{|c|}{ Group 2 (8-12 mm) } & \multicolumn{4}{|c|}{ Group 3 (12-16 mm) } & \multicolumn{4}{|c|}{ Group 4 (>16 mm) } \\
\hline & $\% \mathrm{~N}$ & $\% \mathrm{~V}$ & $\% \mathrm{FO}$ & $\%$ IRI & $\% \mathrm{~N}$ & $\% \mathrm{~V}$ & $\% \mathrm{FO}$ & $\%$ IRI & $\% \mathrm{~N}$ & $\% \mathrm{~V}$ & $\% \mathrm{FO}$ & $\%$ IRI & $\% \mathrm{~N}$ & $\% \mathrm{~V}$ & $\% \mathrm{FO}$ & $\%$ IRI \\
\hline \multicolumn{17}{|l|}{ Algae } \\
\hline \multicolumn{17}{|l|}{ Microalgae } \\
\hline Coscinodiscus $\mathrm{sp}$. & - & - & - & - & 0.14 & 0.02 & 1.82 & 0.01 & - & - & - & - & - & - & - & - \\
\hline Dinoflagellate cysts & 9.48 & 13.75 & 39.02 & 13.85 & 8.21 & 2.04 & 32.73 & 8.33 & 1.67 & 0.13 & 11.76 & 0.48 & - & - & - & - \\
\hline \multicolumn{17}{|l|}{ Macroalgae } \\
\hline Chlorophyta & - & - & - & - & - & - & - & - & - & - & - & - & 2.33 & 0.17 & 20.00 & 0.66 \\
\hline Rhodophyta & - & - & - & - & - & - & - & - & - & - & - & - & 46.51 & 1.53 & 40.00 & 25.49 \\
\hline Phaeophyceae & - & - & - & - & - & - & - & - & - & - & - & - & 6.98 & 0.33 & 40.00 & 3.88 \\
\hline \multicolumn{17}{|l|}{ Tintinnida } \\
\hline Favella sp. & - & - & - & - & 0.14 & 0.00 & 1.82 & 0.01 & - & - & - & - & - & - & - & - \\
\hline Invertebrate eggs & 11.10 & 2.15 & 32.93 & 6.67 & 1.25 & 0.04 & 3.64 & 0.12 & - & - & - & - & - & - & - & - \\
\hline Cyphonautes larvae & 1.04 & 4.69 & 3.66 & 0.32 & 0.56 & 0.32 & 5.45 & 0.12 & 0.42 & 0.09 & 5.88 & 0.07 & - & - & - & - \\
\hline Polychaete larvae & 0.12 & 0.09 & 1.22 & 0.00 & 0.42 & 0.65 & 1.82 & 0.05 & - & - & - & - & 4.65 & 0.09 & 40.00 & 2.51 \\
\hline \multicolumn{17}{|l|}{ Copepoda } \\
\hline Acartia tonsa eggs & 2.08 & 0.36 & 9.76 & 0.36 & 0.70 & 0.02 & 3.64 & 0.06 & - & - & - & - & - & - & - & - \\
\hline Nauplii & 29.36 & 15.31 & 62.20 & 42.45 & 25.03 & 3.16 & 45.45 & 31.85 & 23.33 & 1.21 & 17.65 & 9.82 & - & - & - & - \\
\hline Metanauplii & 3.12 & 5.26 & 17.07 & 2.19 & 2.36 & 0.89 & 18.18 & 1.47 & - & - & - & - & - & - & - & - \\
\hline Calanoid copepodite & 0.35 & 1.56 & 3.66 & 0.11 & 0.14 & 0.18 & 1.82 & 0.01 & 0.42 & 0.15 & 5.88 & 0.08 & - & - & - & - \\
\hline Cyclopoid copepodite & 0.69 & 0.93 & 4.88 & 0.12 & - & - & - & - & - & - & - & - & - & - & - & - \\
\hline Copepodite (Acartia tonsa) & 0.12 & 0.09 & 1.22 & 0.00 & 0.28 & 0.22 & 3.64 & 0.05 & - & - & - & - & - & - & - & - \\
\hline Copepodite (Aetideus armatus) & - & - & - & - & - & - & - & - & 0.42 & 0.26 & 5.88 & 0.09 & - & - & - & - \\
\hline Copepodite (Paracalanus indicus) & 1.39 & 3.14 & 10.98 & 0.76 & 2.23 & 2.72 & 9.09 & 1.12 & 0.83 & 0.33 & 5.88 & 0.16 & - & - & - & - \\
\hline Copopodite (Oncaea sp.) & 0.35 & 0.32 & 3.66 & 0.04 & 0.42 & 0.14 & 3.64 & 0.05 & - & - & - & - & - & - & - & - \\
\hline Paracalanus indicus & 0.46 & 4.50 & 3.66 & 0.28 & 2.09 & 4.03 & 12.73 & 1.94 & 23.33 & 13.65 & 47.06 & 39.44 & - & - & - & - \\
\hline Oncaea sp. & 0.35 & 1.17 & 3.66 & 0.08 & 0.70 & 1.21 & 9.09 & 0.43 & - & - & - & - & - & - & - & - \\
\hline Sappirina nigromaculata & - & - & - & - & - & - & - & - & 0.42 & 2.01 & 5.88 & 0.32 & - & - & - & - \\
\hline Zaus sp. & 0.23 & 0.13 & 2.44 & 0.01 & - & - & - & - & - & - & - & - & - & - & - & - \\
\hline Euterpina acutifrons & 0.46 & 0.17 & 1.22 & 0.01 & - & - & - & - & - & - & - & - & - & - & - & - \\
\hline Microsetella rosea & - & - & - & - & 0.56 & 0.05 & 1.82 & 0.03 & - & - & - & - & - & - & - & - \\
\hline Nauplii remains & 7.86 & 4.03 & 37.80 & 6.87 & 2.64 & 0.44 & 18.18 & 1.39 & 2.08 & 0.06 & 17.65 & 0.86 & - & - & - & - \\
\hline Copepodite remains & 0.58 & 0.43 & 6.10 & 0.09 & 0.83 & 0.36 & 10.91 & 0.32 & 0.83 & 0.37 & 5.88 & 0.16 & - & - & - & - \\
\hline Copepod remains & 3.58 & 7.75 & 15.85 & 2.74 & 4.59 & 8.76 & 21.82 & 7.24 & 9.58 & 6.54 & 52.94 & 19.34 & - & - & - & - \\
\hline \multicolumn{17}{|l|}{ Cirripedia } \\
\hline Nauplii _.. & 18.73 & 14.65 & 32.93 & 16.79 & 32.68 & 5.16 & 25.45 & 23.95 & 18.33 & 0.93 & 11.76 & 5.14 & - & - & - & - \\
\hline Metanauplii & 0.12 & 0.17 & 1.22 & 0.01 & 1.53 & 0.51 & 7.27 & 0.37 & 3.75 & 0.94 & 11.76 & 1.25 & - & - & - & - \\
\hline Cypris larvae & - & - & - & - & 1.81 & 5.88 & 10.91 & 2.08 & 2.92 & 3.61 & 17.65 & 2.61 & - & - & - & - \\
\hline Isopoda & - & - & - & - & 0.14 & 0.01 & 1.82 & 0.01 & - & - & - & - & - & - & - & - \\
\hline \multicolumn{17}{|l|}{ Euphausiacea } \\
\hline Metanauplii & 0.12 & 0.75 & 1.22 & 0.02 & 0.14 & 0.51 & 1.82 & 0.03 & - & - & - & - & - & - & - & - \\
\hline Calyptopis I & - & - & - & - & 0.28 & 0.51 & 3.64 & 0.07 & - & - & - & - & - & - & - & - \\
\hline \multicolumn{17}{|l|}{ Bivalvia } \\
\hline Bivalve larvae & 1.27 & 1.65 & 13.41 & 0.60 & 0.83 & 0.16 & 9.09 & 0.22 & - & - & - & - & - & - & - & - \\
\hline Perumytilus purpuratus & - & - & - & - & - & - & - & - & - & - & - & - & 2.33 & 1.07 & 20.00 & 0.90 \\
\hline Gastropoda & & & & & & & & & & & & & & & & \\
\hline Gastropod larvae & 2.89 & 7.29 & 23.17 & 3.60 & 4.73 & 3.99 & 18.18 & 3.94 & 8.33 & 47.57 & 11.76 & 14.91 & - & - & - & - \\
\hline Unidentified gastropod & - & - & - & - & - & - & - & - & - & - & - & - & 2.33 & 0.11 & 20.00 & 0.65 \\
\hline Siphonarioidea & - & - & - & - & - & - & - & - & - & - & - & - & 9.30 & 2.29 & 20.00 & 3.08 \\
\hline Pisces & & & & & & & & & & & & & & & & \\
\hline Unidentified eggs & - & - & - & - & 1.25 & 30.29 & 12.73 & 9.98 & 0.83 & 8.27 & 11.76 & 2.43 & - & - & - & - \\
\hline Engraulis ringens eggs & 0.23 & 1.80 & 1.22 & 0.04 & 0.28 & 5.46 & 1.82 & 0.26 & - & - & - & - & - & - & - & - \\
\hline Normanichthys crockeri eggs & - & - & - & - & 0.42 & 8.11 & 1.82 & 0.39 & 0.83 & 9.10 & 5.88 & 1.32 & - & - & - & - \\
\hline Chitinous remains & 2.54 & 2.89 & 17.07 & 1.42 & 0.97 & 0.44 & 9.09 & 0.32 & - & - & - & - & - & - & - & - \\
\hline Digested remains & 0.92 & 3.58 & 7.32 & 0.50 & 1.39 & 11.85 & 10.91 & 3.59 & 1.25 & 3.81 & 11.76 & 1.35 & 23.26 & 93.55 & 40.00 & 61.98 \\
\hline Unidentified prey & 0.46 & 1.39 & 2.44 & 0.07 & 0.28 & 1.86 & 3.64 & 0.19 & 0.42 & 0.96 & 5.88 & 0.18 & 2.33 & 0.87 & 20.00 & 0.85 \\
\hline
\end{tabular}




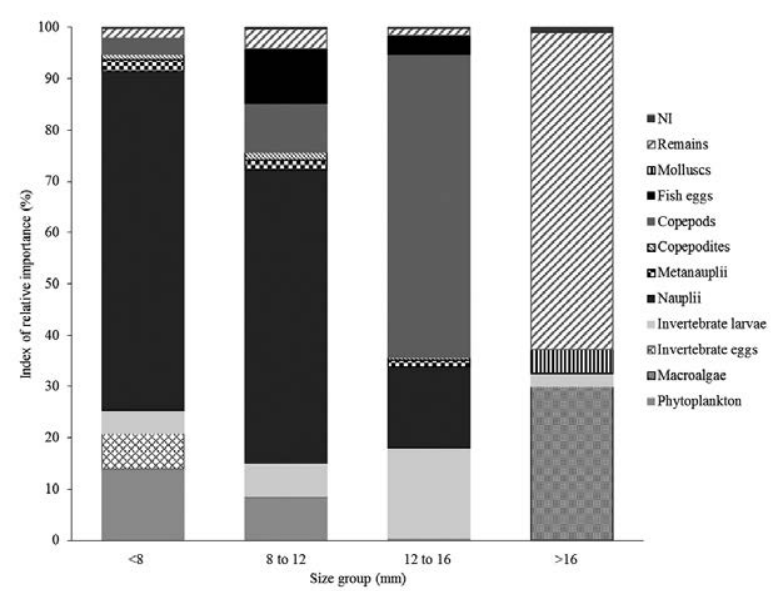

Fig. 5. - Percentage of index of relative importance (\%IRI) of prey ingested by $S$. sanguineus during early ontogenetic development, according to size group (NI is non-identified prey).
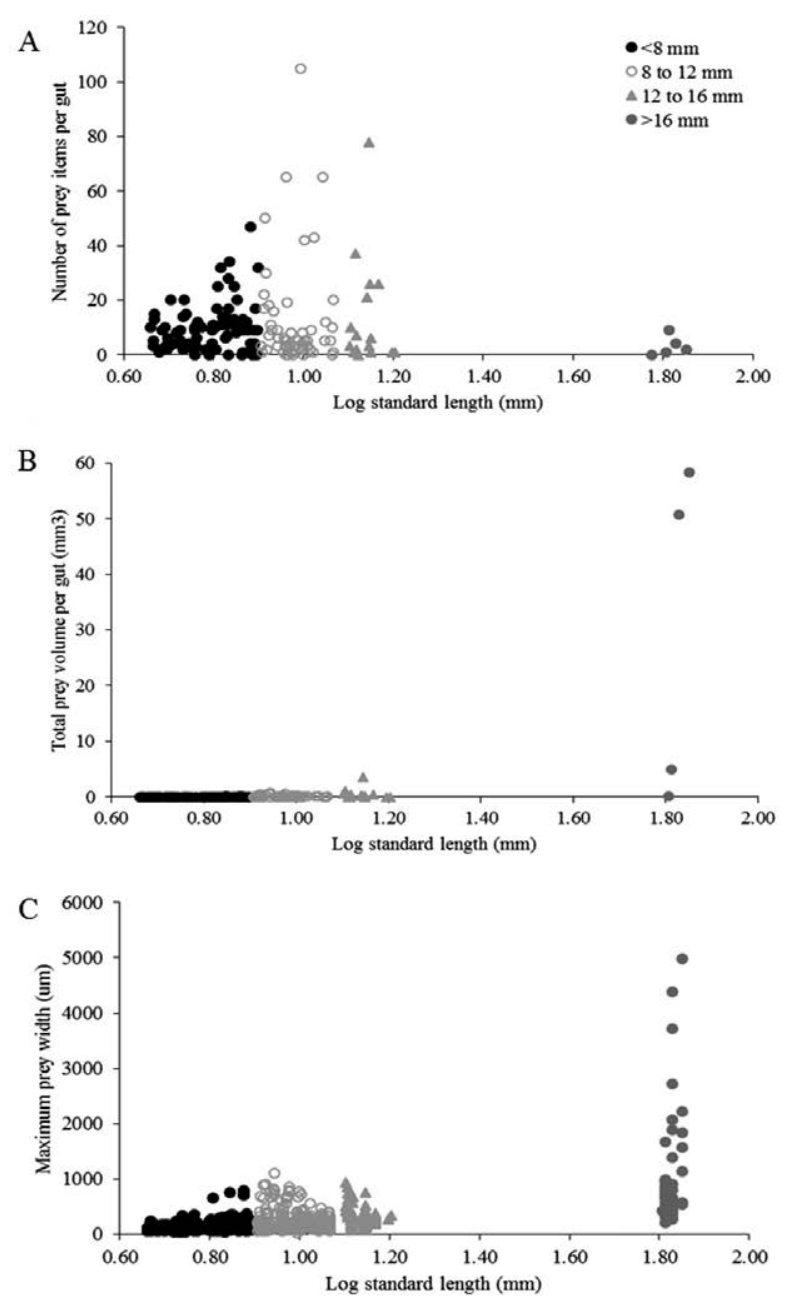

Fig. 6. - Relationship between feeding success and size of the individuals of $S$. sanguineus: A, number of prey items per gut (PIPG) and standard length (SL); B, total prey volume per gut (TPVG) and SL; and C, maximum prey width (MPW) and SL.

had prey items largely digested $(61.98 \% \%$ IRI) and red $(25.49 \%)$ and brown (3.88\%) macroalgae (Fig. 5), showing an important change in the prey items, varying from pelagic to benthic prey.

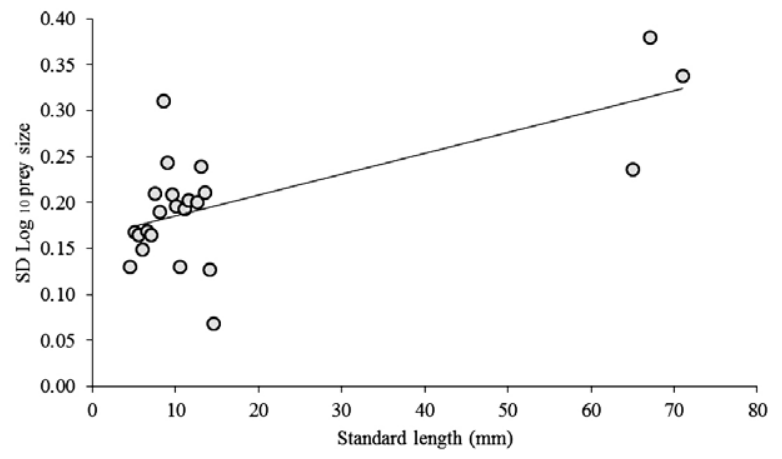

Fig. 7. - Trophic niche breadth variation of S. sanguineus during early ontogenetic development.

\section{Feeding success during early development}

PIPG did not vary significantly among size groups (one-way ANCOVA, $\mathrm{F}=0.27, \mathrm{P}=0.89$, Fig. 6A), but TVPG did $\left(\mathrm{F}=11.61, \mathrm{P}=6.65 \times 10^{-7}\right.$, Fig. $\left.6 \mathrm{~B}\right)$. The largest differences in TVPG occurred between individuals $<8 \mathrm{~mm}$ SL and $>16 \mathrm{~mm}$ SL $\left(\mathrm{F}=31.39, \mathrm{P}=2.61 \times 10^{-7}\right)$. Finally, one-way ANCOVA indicated no significant differences in the maximum prey among size groups $(\mathrm{F}=2.58, \mathrm{P}=0.051$, Fig. 6C).

\section{Trophic niche breadth}

The regression between SL and SD of log-transformed MPW was positive and significant $\left(\mathrm{R}^{2}=0.418\right.$, $\mathrm{P}<0.05)$, and the trophic niche breadth was $0.201 \pm 0.07$ (Fig. 7). This result means that the trophic niche increases with larval length and the individuals of $S$. sanguineus are capable of ingesting wider prey as they grow.

\section{Multivariate analyses of diet variability}

One-way PERMANOVA detected significant differences in the diet composition among size groups (pseudo-F=4.31, $\mathrm{P}=0.0001$ ) and SIMPER analysis indicated that the largest dissimilarity $(99.31 \%)$ in the diet composition occurred between small $(<8 \mathrm{~mm} \mathrm{SL})$ and transformed juveniles ( $>16 \mathrm{~mm} \mathrm{SL}$ ), and that the dissimilarities between contiguous size groups were relatively high $(>80 \%$, Table 5$)$. The prey items that explain the differences among size groups were copepod nauplii, cirriped nauplii, Paracalanus indicus and Rodophyta (Table 5).

\section{Partial Least Squares}

PLS analysis indicated significant, but low covariance $(\mathrm{RV}=0.045, \mathrm{P}=0.0104)$ between morphometrics changes and variations in diet (expressed by number of prey per item). The PLS 1 explained $90.31 \%$ of the covariance. The regression between shape changes of clingfish (Block 1) and diet composition (Block 2) was low but significant $\left(\mathrm{R}^{2}=0.243, \mathrm{P}=0.032\right)$ (Fig. 8A). Likewise, the PLS analysis between the morphometrics changes and variations in the prey volume showed significant but low covariance $(\mathrm{RV}=0.096, \mathrm{P}<0.001)$. 
Table 5. - Results of the analysis of percentage similarity (SIMPER) of the diet composition of the clingfish $S$. sanguineus.

\begin{tabular}{|c|c|c|c|}
\hline Groups & \%Dissimilarity & Taxa & $\%$ Contribution \\
\hline \multirow[t]{4}{*}{ G1 vs G2 } & \multirow[t]{4}{*}{$86.13 \%$} & Copepod nauplii & $22.32 \%$ \\
\hline & & Barnacle nauplii & $17.83 \%$ \\
\hline & & Dinoflagellate cyst & $7.81 \%$ \\
\hline & & Invertebrate eggs & $7.54 \%$ \\
\hline \multirow[t]{4}{*}{ G1 vs G3 } & \multirow[t]{4}{*}{$94.33 \%$} & Copepod nauplii & $21.32 \%$ \\
\hline & & Paracalanus indicus & $13.74 \%$ \\
\hline & & Barnacle nauplii & $13.24 \%$ \\
\hline & & Copepod remains & $9.21 \%$ \\
\hline \multirow[t]{4}{*}{ G1 vs G4 } & \multirow[t]{4}{*}{$99.31 \%$} & Rhodophyta & $18.64 \%$ \\
\hline & & Copepod nauplii & $15.23 \%$ \\
\hline & & Digested remains & $12.87 \%$ \\
\hline & & Barnacle nauplii & $8.11 \%$ \\
\hline \multirow[t]{4}{*}{$\mathrm{G} 2$ vs $\mathrm{G} 3$} & \multirow[t]{4}{*}{$91.17 \%$} & Copepod nauplii & $18.63 \%$ \\
\hline & & Paracalanus indicus & $15.92 \%$ \\
\hline & & Barnacle nauplii & $14.87 \%$ \\
\hline & & Copepod remains & $10.98 \%$ \\
\hline \multirow[t]{4}{*}{ G2 vs G4 } & \multirow[t]{4}{*}{$98.64 \%$} & Rhodophyta & $19.54 \%$ \\
\hline & & Digested remains & $14.65 \%$ \\
\hline & & Copepod nauplii & $11.97 \%$ \\
\hline & & Barnacle nauplii & $9.46 \%$ \\
\hline \multirow[t]{4}{*}{ G3 vs G4 } & \multirow[t]{4}{*}{$98.51 \%$} & Rhodophyta & $19.62 \%$ \\
\hline & & Digested remains & $15.17 \%$ \\
\hline & & Paracalanus indicus & $14.22 \%$ \\
\hline & & Copepod remains & $8.83 \%$ \\
\hline
\end{tabular}
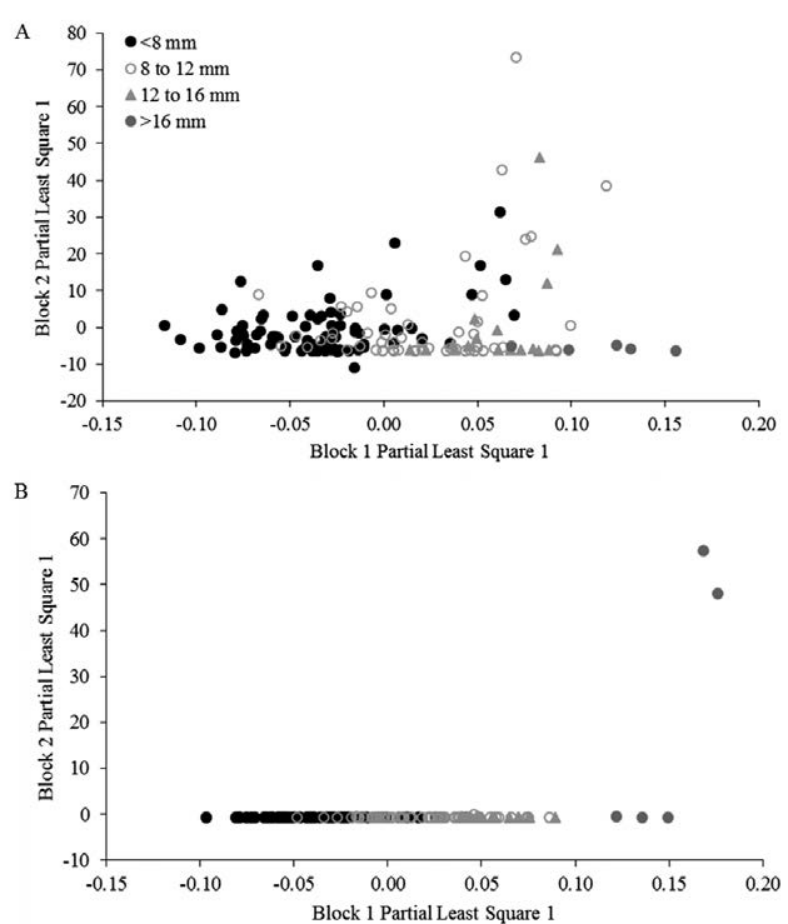

Fig 8. - Partial least square between morphometric changes (Block 1) and diet composition (Block 2) using (A) prey number and, (B) prey volume.

The PLS 1 explained $99.89 \%$ of the covariance and the regression between shape changes (Block 1) and prey volume (Block 2) was significant but low $\left(\mathrm{R}^{2}=0.386\right.$, $\mathrm{P}<0.001$ ) (Fig. 8B). These results suggest that major changes in the shape of clingfish are decoupled with higher variations in feeding habits during habitat transition.

\section{DISCUSSION}

As in the larval fish development of other species (Loy et al. 1998, 2001, Russo et al. 2007, 2009), changes in $S$. sanguineus are very rapid for small sizes, showing an allometric growth and decrease with growth up to an apparent stable stage. Indeed, the growth trajectory shows a two-stage pattern: the first stage is characterized by faster shape changes in a small size interval and the second stage by a change in size with small amounts of changes in shape (Loy et al. 1998). The high rate of changes in the first stages of development could be attributed to the need of small individuals to acquire new morphological characters quickly, also changing their diet (Loy et al. 1998, 2001, Urho 2002).

Theoretical scaling models (Richard and Wainwright 1995) predict that fishes belonging to larger size classes benefit from relatively high force-generation capacity, but juveniles are expected to be relatively faster, which may allow them to exploit more agile prey (Herrel et al. 2006). Nonetheless, S. sanguineus juveniles seem to have lower swimming performance than larvae, and graze mostly on ephemeral algae $(\mathrm{Mu}-$ ñoz and Ojeda 1997).

According to present results, the greatest changes in shape occurred from hatching to $12 \mathrm{~mm}$ SL, before the habitat change. In other fish species, the greatest shape changes occur in a size range when transition of habitats take place (Loy et al. 1998, 2001) or even later (Frédérich et al. 2012). However, in our study there is a size range that is not represented in the samples, corresponding to individuals just before settlement occurs, which may potentially affect our results.

The FI was high $(\geq 80 \%)$ throughout the early development of $S$. sanguineus, as was observed by VeraDuarte and Landaeta (2016) for the labrisomid blenny Auchenionchus variolosus in central Chile. These values are higher than those of others species with a similar habitat change along Chilean coasts, such as Hypsoblennius sordidus, Patagonothothen tessellata and Myxodes viridis (Balbontín et al. 1997, Salas-Berrios et al. 2013, Ochoa-Muñoz et al. 2013).

The diet of smaller individuals of $S$. sanguineus (up to $12 \mathrm{~mm}$ ) showed a preference for copepod nauplii, as has been reported for several other marine fish larvae from central and southern Chile, such as the clinid Myxodes viridis (Ochoa-Muñoz et al. 2013) and the labrisomid blenny Auchenionchus variolosus (Vera-Duarte and Landaeta 2016). Other important prey during the larval development were cirriped nauplii, which are highly abundant in nearshore waters off central Chile, particularly near density fronts (Vargas et al. 2006). For larger larvae (up to $16 \mathrm{~mm}$ ) Paracalanus indicus copepods, also a frequently abundant calanoid species in coastal waters of the Humboldt Current System (Hidalgo et al. 2010, 2012, Pino-Pinuer et al. 2014), were the most important prey item, so the different copepods stages are a fundamental item in the diet of $S$. sanguineus larvae. Finally, this is the first report of postlarval clingfishes preying on pelagic fish eggs. 
The number of prey per gut and prey width were independent of SL, contrary to what Salas-Berrios et al. (2013) and Vera-Duarte and Landaeta (2016) found for P. tessellata and A. variolosus. For those species, a significant increase occurred in the number and width of ingested prey together with the increase of larval length. However, the range of the number of prey per gut varied from 0 to 105 in $S$. sanguineus, which is a greater range than in other coastal fishes with complex life cycles, such as $M$. viridis, $P$. tessellata and A. variolosus (Ochoa-Muñoz et al. 2013, Salas-Berrios et al. 2013, Vera-Duarte and Landaeta 2016). This result suggests that $S$. sanguineus is opportunistic and less selective during its early development and in adult feeding (Paine and Palmer 1978, Muñoz and Ojeda 1997). The ingested prey volume showed a positive relation to body length, suggesting that as the clingfish grow they prefer prey of greater size. This increase in prey volume coincides with the results for diet composition.

The increase of trophic niche breadth with larval size is an unexpected result, considering the hypothesis of Llopiz (2013), who reported that for fish larvae niche breadth does not change with growth at middle latitudes. For example, the larval labrisomid blenny $A$. variolosus from central Chile shows a trophic niche breath, which is independent of larval size (Vera-Duarte and Landaeta 2016).

Adult $S$. sanguineus graze mainly on ephemeral algae but also eat animals (gastropods and barnacles), showing no clear trophic relationship with any feeding guild (i.e. carnivorous species and omnivorous-herbivorous species, Muñoz and Ojeda 1997). Grazing activities in juveniles may induce morphological changes to optimize biting performance in the new environment (Palmer 1979). Biting strength in fishes that consume hard, benthic prey plays a central role in shaping feeding performance and patterns of prey use during ontogeny, as in triggerfish (Turingan et al. 1995). Feeding on different diets requires different modes of feeding, which could set up differences in the loading encountered by bones and result in morphological changes (Wimberger 1991).

Based on our results, it is plausible that a relationship occurs between shape changes of $S$. sanguineus during their early life history and feeding success and diet composition variability; throughout their development these fish exhibit an elongation of their visceral cavity and their mouth, which would allow them to ingest higher volume prey as they grow. This is why the early stages of this species pass through consuming copepods nauplii to bigger prey such as fish eggs and the copepods Paracalanus indicus. The length of the intestine has been associated with the degree of herbivory in the diet of fishes. Longer intestines have been linked to diets with a higher consumption of vegetable prey (Piet 1998, Elliott and Bellwood 2003, Davis et al. 2012). Therefore, this lengthening of the visceral cavity could also be explained by the high consumption of macroalgae by juveniles of $S$. sanguineus.

The PLS showed covariance between the shape changes and the diet composition changes during the growth of the clingfish, prey number and prey volume. However, the regression between the shape variations and feedings changes was low (in both cases), indicating that the two processes were temporally decoupled. This is opposite of what was described by Russo et al. (2008), who found a high degree of relation between shape and diet changes, and that these processes were coupled in juveniles of two sympatric species of the family Pleuronectidae. The greatest shape changes and allometric growth occurred up to $12 \mathrm{~mm}$, while the largest feeding differentiation occurred after $16 \mathrm{~mm}$. This suggests that the shape changes precede functional changes (related to the feeding ecology), and occur during the early ontogeny of $S$. sanguineus, involving an important habitat change from the water column to the benthos.

\section{ACKNOWLEDGEMENTS}

This research was funded by the projects Fondecyt 1120868 and Fondecyt 1150296 (Comisión Nacional de Investigación en Ciencia y Tecnología, CONICYT), Chile. We appreciate the comments and suggestions of the reviewers and the editor Dr J.J. Govoni.

\section{REFERENCES}

Anderson M.J. 2001. A new method for non-parametric multivariate analysis of variance. Austral Ecol. 26: 32-46. https://doi.org/10.1111/j.1442-9993.2001.01070.pp.x

Balbontín F., Llanos A., Valenzuela V. 1997. Sobreposición trófica e incidencia alimentaria en larvas de peces de Chile central. Rev. Chil. Hist. Nat. 70: 381-390.

Bookstein F.L. 1991. Morphometric tools for landmark data. Geometry and Biology. Cambridge University Press, $455 \mathrm{pp}$.

Cass-Calay S.L. 2003. The feeding ecology of larval Pacific hake (Merluccius productus) in the California Current region: an updated approach using a combined OPC/MOCNESS to estimate prey biovolume. Fish. Oceanogr. 12: 34-48. https://doi.org/10.1046/j.1365-2419.2003.00206.x

Cavalcanti M.J., Monteiro L.R., Lopes P.R.D. 1999. Landmarkbased morphometric analysis in selected species of serranid fishes (Perciformes: Teleostei). Zool. Stud. 38: 287-294.

Contreras J.E., Landaeta M.F., Plaza G., et al. 2013. The contrasting hatching patterns and larval growth of two sympatric clingfishes inferred by otolith microstructure analysis. Mar. Freshw. Res. 64: 157-167. https://doi.org/10.1071/MF12232

Cortés E. 1997. A critical review of methods of studying fish feeding based on analysis of stomach contents: application to elasmobranch fishes. Can. J. Fish. Aquat. Sci. 54: 726-738. https://doi.org/10.1139/f96-316

Costa C., Cataudella S. 2007. Relationship between shape and trophic ecology of selected species of Sparids of the Caprolace coastal lagoon (Central Tyrrhenian sea). Environ. Biol. Fish. 78: $115-123$. https://doi.org/10.1007/s10641-006-9081-9

Davis A.M., Pusey B.J., Pearson R.G. 2012. Trophic ecology of terapontid fishes (Pisces: Terapontidae): the role of morphology and ontogeny. Mar. Freshw. Res. 63: 128-141. https://doi.org/10.1071/MF11105

Dryden I.L., Mardia K.V. 1998. Statistical shape analysis. Chichester: Wiley.

Elliott J.P., Bellwood D.R. 2003. Alimentary tract morphology and diet in three coral reef fish families. J. Fish Biol. 63: 1598-1609. https://doi.org/10.1111/j.1095-8649.2003.00272.x

Farré M., Tuset V.M., Maynou F., et al. 2016. Selection of landmarks and semilandmarks in fishes for geometric morphometric analyses: a comparative study based on analytical methods. Sci. Mar. 80: 175-186.

https://doi.org/10.3989/scimar.04280.15A

Frédérich B., Adriaens D., Vandewalle P. 2008. Ontogenetic shape 
changes in Pomacentridae (Teleostei, Perciformes) and their relationships with feeding strategies: a geometric morphometric approach. Biol. J. Linn. Soc. 95: 92-105. https://doi.org/10.1111/j.1095-8312.2008.01003.x

Frédérich B., Colleye O., Lepoint G., et al. 2012. Mismatch between shape changes and ecological shifts during the post-settlement growth of the surgeonfish, Acanthurus triostegus. Frontiers Zool. 9: 8 . https://doi.org/10.1186/1742-9994-9-8

Gonçalves E.J., Barbosa M., Cabral H.N., et al. 2002. Ontogenetic shifts in patterns of microhabitat utilization in the small-headed clingfish, Apletodon dentatus (Gobiesocidae). Environ. Biol. Fish. 63: 333-339. https://doi.org/10.1023/A:1014302319622

Gould S.J. 1966. Allometry and size in ontogeny and phylogeny. Biol. Rev. 41: 587-640. https://doi.org/10.1111/j.1469-185X.1966.tb01624.x

Hernández-Miranda E., Veas R., Espinoza C.V., et al. 2009. The use of otoliths and larval abundance for studying the spatial ecology of the blenny Scartichthys viridis (Valenciennes, 1836) in coastal central Chile. Rev. Biol. Mar. Oceanogr. 44: 619-633. https://doi.org/10.4067/S0718-19572009000300009

Herrel A., Joachim R., Vanhooydonck B., et al. 2006. Ecological consequences of ontogenetic changes in head shape and bite performance in the Jamaican lizard Anolis lineatopus. Biol. J. Linn. Soc. 89: 443-454. https://doi.org/10.1111/j.1095-8312.2006.00685.x

Hidalgo P., Escribano R., Vergara O., et al. 2010. Patterns of copepod diversity in the Chilean coastal upwelling system. DeepSea Res. II 57: 2089-2097. https://doi.org/10.1016/j.dsr2.2010.09.012

Hidalgo P., Escribano R., Fuentes M., et al. 2012. How coastal upwelling influences spatial patterns of size-structured diversity of copepods off central-southern Chile (summer 2009). Prog. Oceanogr. 92-95: 134-145. https://doi.org/10.1016/j.pocean.2011.07.012

Ibáñez A.L., Cowx I.G., O'Higgins P. 2007. Geometric morphometric analysis of fish scales for identifying genera, species, and local populations within the Mugilidae. Can. J. Fish. Aquat. Sci. 64: 1091-1100. https://doi.org/10.1139/f07-075

Kerschbaumer M., Sturmbauer C. 2009. The utility of geometric morphometrics to elucidate pathways of cichlid fish evolution. Int. J. Evol. Biol. 2011: 1-8. https://doi.org/10.4061/2011/290245

Klingenberg C.P. 2011. MorphoJ: an integrated software package for geometric morphometrics. Mol. Ecol. Resour. 11: 353-357. https://doi.org/10.1111/j.1755-0998.2010.02924.x

Klingenberg C.P. 2013. Visualizations in geometric morphometrics: how to read and how to make graphs showing shape changes. Hystrix 24: 15-24. http://dx.doi.org/10.4404/hystrix-24.1-7691

Klingenberg C.P. 2016. Size, shape, and form: concepts of allometry in geometric morphometrics. Dev. Genes Evol. 226: 113-137. https://doi.org/10.1007/s00427-016-0539-2

Klingenberg C.P., Ekau W. 1996. A combined morphometric and phylogenetic analysis of an ecomorphological trend: pelagization in Antarctic fishes (Perciformes: Nototheniidae). Biol. J. Linn. Soc. 59: 143-177. https://doi.org/10.1111/j.1095-8312.1996.tb01459.x

Landaeta M.F., Suárez-Donoso N., Bustos C.A., et al. 2011. Feeding habits of larval Maurolicus parvipinnis (Pisces: Sternoptychidae) in Patagonian fjords. J. Plankton Res. 33: 1813-1824. https://doi.org/10.1093/plankt/fbr081

Landaeta M.F., Bustos C.A., Contreras J.E., et al. 2015. Larval fish feeding ecology, growth and mortality from two basins with contrasting environmental conditions of an inner sea of northern Patagonia, Chile. Mar. Environ. Res. 106: 19-29. https://doi.org/10.1016/j.marenvres.2015.03.003

Lecchini D. 2005. Spatial and behavioural patterns of reef habitat settlement by fish larvae. Mar. Ecol. Prog. Ser. 301: 247-252. https://doi.org/10.3354/meps301247

Llopiz J.K. 2013. Latitudinal and taxonomic patterns in the feeding ecologies of fish larvae: A literature synthesis. J. Mar. Syst. 109-110: 69-77. https://doi.org/10.1016/j.jmarsys.2012.05.002

Lopes M., Murta A.G., Cabral H.N. 2006. Discrimination of snipefish Macroramphosus species and boardfish Capros aper morphotypes through multivariate analysis of the body shape. Helgoland Mar. Res. 60: 18-24. https://doi.org/10.1007/s10152-005-0010-7

Loy A., Mariani L., Bertelletti M., et al. 1998. Visualizing allometry: geometric morphometrics in the study of shape changes in the early stages of the two-banded sea bream, Diplodus vulgaris (Perciformes, Sparidae). J. Morph. 237: 137-146.

h t t p s : / / d o i.org / 10.1002 / ( S I C I ) 1097 4687(199808)237:2<137::AID-JMOR5>3.0.CO;2-Z

Loy A., Bertelleti M., Costa C., et al. 2001. Shape changes and growth trajectories in the early stages of three species of the genus Diplodus (Perciformes, Sparidae). J. Morph. 250: 24-33. https://doi.org/10.1002/jmor.1056

McCormick M.I., Makey L.J. 1997. Post-settlement transition in coral reef fishes: overlooked complexity in niche shifts. Mar. Ecol. Prog. Ser. 153: 247-257. https://doi.org/10.3354/meps 153247

Mitteroecker P., Gunz P. 2009. Advances in geometric morphometrics. Evol. Biol. 36: 235-247. https://doi.org/10.1007/s11692-009-9055-x

Mitteroecker P., Gunz P., Bernhard M., et al. 2004. Comparison of cranial ontogenetic trajectories among great apes and humans. J. Hum. Evol. 46: 679-698. https://doi.org/10.1016/j.jhevol.2004.03.006

Motta P.J., Kotrschal K.M. 1992. Correlative, experimental, and comparative experimental approaches in ecomorphology. Neth. J. Zool. 42: 400-415. https://doi.org/10.1163/156854291X00414

Muñoz A.A., Ojeda F.P. 1997. Feeding guild structure of a rocky intertidal fish assemblage in central Chile. Environ. Biol. Fish. 49: 471-479.

https://doi.org/10.1023/A:1007305426073

Norton S.F. 1991. Capture success and diet of cottid fishes: the role of predator morphology and attack kinematics. Ecology 72: 1807-1819. https://doi.org/10.2307/1940980

Ochoa-Muñoz M.J., Valenzuela C.P., Toledo S., et al. 2013. Feeding of a larval clinid fish in a microtidal estuary from southern Chile. Rev. Biol. Mar. Oceanogr. 48: 45-57. https://doi.org/10.4067/S0718-19572013000100005

Paine R., Palmer A.R. 1978. Sicyases sanguineus: A unique trophic generalist from the Chilean intertidal zone. Copeia 1: 75-81. https://doi.org/10.2307/1443824

Palmer A.R. 1979. Fish predation and the evolution of gastropod shell sculpture: experimental and geographic evidence. Evolution 33: 697-713. https://doi.org/10.2307/2407792

Pearre S. Jr. 1986. Ratio-based trophic niche breadths of fish, the Sheldon spectrum, and the size-efficiency hypothesis. Mar. Ecol. Prog. Ser. 24: 299-314. https://doi.org/10.3354/meps027299

Pérez R. 1981. Desarrollo embrionario y larval de los pejesapos $\mathrm{Si}$ cyases sanguineus y Gobiesox marmoratus en la Bahía de Valparaíso, Chile, con notas sobre su reproducción (Gobiesocidae: Pisces). Invest. Mar. (Chile) 9: 1-24.

Piet G.J. 1998. Ecomorphology of a size-structured tropical freshwater fish community. Environ. Biol. Fish. 51: 67-86. https://doi.org/10.1023/A:1007338532482

Pino-Pinuer P., Escribano R., Hidalgo P., et al. 2014. Copepod community response to variable upwelling conditions off central southern Chile during 2002-2004 and 2010-2012. Mar. Ecol. Prog. Ser. 515: 83-95. https://doi.org/10.3354/meps 11001

Ponton D., Carassou L., Raillard S., et al. 2013. Geometric morphometrics as a tool for identifying emperor fish (Lethrinidae) larvae and juveniles. J. Fish Biol. 83: 14-27. https://doi.org/10.1111/jfb.12138

Reiss C.S., Anis A., Taggart C.T., et al. 2002. Relationships among vertically structured in situ measures of turbulence, larval fish abundance and feeding success and copepods on Western Bank, Scotian Shelf. Fish. Oceanogr. 11: 156-174. https://doi.org/10.1046/j.1365-2419.2002.00194.x

Richard B.A., Wainright P.C. 1995. Scaling of the feeding mechanism of largemouth bass (Micropterus salmoides): kinematics of prey capture. J. Exp. Biol. 198: 419-433.

Rohlf F.J., Slice D.E. 1990. Extensions of the Procrustes method for the optimal superimposition of landmarks. Syst. Zool. 39: 40-59. https://doi.org/10.2307/2992207

Russo T., Costa C., Cataudella S. 2007. Correspondence between shape and feeding habit change throughout ontogeny of gilthead sea bream Sparus aurata L., 1758. J. Fish Biol. 71: 629-656. 
https://doi.org/10.1111/j.1095-8649.2007.01528.x

Russo T., Pulcini D., O’Leary Á., et al. 2008. Relationship between body shape and trophic niche segregation in two closely related sympatric fishes. J. Fish Biol. 73: 809-828. https://doi.org/10.1111/j.1095-8649.2008.01964.x

Russo T., Pulcini D., Bruner E., et al. 2009. Shape and size variation: Growth and development of the dusky grouper (Epinephelus marginatus Lowe, 1834). J. Morphol. 270: 83-96. https://doi.org/10.1002/jmor.10674

Salas-Berríos F., Valdés-Aguilera J., Landaeta M.F., et al. 2013. Feeding habits and diet overlap of marine fish larvae from the peri-Antarctic Magellan region. Pol. Biol. 36: 1401-1414. https://doi.org/10.1007/s00300-013-1359-8

Sassa C., Kawaguchi K. 2004. Larval feeding habits of Diaphus garmani and Myctophum asperum (Pisces: Myctophidae) in the transition region of the western North Pacific. Mar. Ecol. Prog. Ser. 278: 279-290. https://doi.org/10.3354/meps278279

Sidlaukas B.L., Mol J.H., Vari R.P. 2011. Dealing with allometry in linear and geometric morphometrics: a taxonomic case study in the Leporinus cylindriformis group (Characiformes: Anostomidae) with description of a new species from Suriname. Zool. J. Linn. Soc. 162: 103-130. https://doi.org/10.1111/j.1096-3642.2010.00677.x

Sun J., Liu D. 2003. Geometric models for calculating cell biovolume and surface area for phytoplankton. J. Plankton Res. 25: 1331-1346. https://doi.org/10.1093/plankt/fbg096

Tojeira I., Faria A.M., Henriques S., et al. 2012. Early development and larval behaviour of two clingfishes, Lepadogaster purpurea and Lepadogaster lepadogaster (Pisces: Gobiesocidae). Environ. Biol. Fish. 93: 449-459. https://doi.org/10.1007/s10641-011-9935-7

Turingan R.G., Wainwright P.C., Hensley D.A. 1995. Interpopulation variation in prey use and feeding biomechanics in Carib- bean triggerfishes. Oecologia 102: 296-304. https://doi.org/10.1007/BF00329796

Urho L. 2002. The importance of larvae and nursery areas for fish production. Finnish Game and Fisheries Research Institute.

Usmar N.R. 2012. Ontogenetic diet shifts in snapper (Pagrus auratus: Sparidae) within a New Zealand estuary. N. Z. J. Mar. Fresh. Res. 46: 31-46. https://doi.org/10.1080/00288330.2011.587824

Vargas C.A., Narváez D.A., Piñones A., et al. 2006. River plume dynamic influences transport of barnacle larvae in the inner shelf off central Chile. J. Mar. Biol. Ass. U.K. 86: 1057-1065. https://doi.org/10.1017/S0025315406014032

Vera-Duarte J., Landaeta M.F. 2016. Diet of labrisomid blenny Auchenionchus variolosus (Valenciennes, 1836) (Labrisomidae) during its larval development off central Chile (20122013). J. Appl. Ichthyol. 32: 46-54 https://doi.org/10.1111/jai.12935

Wainwright P.C. 1991. Ecomorphology: experimental functional anatomy for ecological problems. Amer. Zool. 31: 680-693. https://doi.org/10.1093/icb/31.4.680

Wainwright P.C., Richard B.A. 1995. Predicting patterns of prey use from morphology of fishes. Environ. Biol. Fish. 44: 97-113. https://doi.org/10.1007/978-94-017-1356-6_7

Weston E.M. 2003. Evolution of ontogeny in the hippopotamus skull: using allometry to dissect developmental change. Biol. J. Linn. Soc. 80: 625-638. https://doi.org/10.1111/j.1095-8312.2003.00263.x

Wimberger P.H. 1991. Plasticity of jaw and skull morphology in the neotropical cichlids Geophagus brasiliensis and $G$. steindachneri. Evolution 45: 1545-1563. https://doi.org/10.2307/2409778

Zelditch M.L., Swiderski D.L., Sheets H.D. 2012. Geometric Morphometrics for Biologists: A Primer. Second Edition, Academic Press, 475 pp. 